Article

\title{
Effect of Deposit Mobilization on the Financial Sustainability of Rural Saving and Credit Cooperatives: Evidence from Ethiopia
}

\author{
Girma Jirata Duguma $₫$ and Jiqin Han * \\ College of Economics and Management, Nanjing Agricultural University, No. 1 Weigang, \\ Nanjing 210095, China; girmajirata@yahoo.com \\ * Correspondence: jhan@njau.edu.cn; Tel.: +86-258-4399-803
}

Received: 25 July 2018; Accepted: 18 September 2018; Published: 21 September 2018

check for updates

\begin{abstract}
Increasing institutional capital through deposit mobilization keeps the cost of capital low, thus leading to financial sustainability. However, little is known about how deposit mobilization affects financial sustainability. Using balanced panel data of 166 rural savings and credit cooperatives (RUSACCOs) from Ethiopia over the period of 2014-2016, we investigated the effect of deposit mobilization on financial sustainability. The results of the panel regression estimates showed that, among the deposits mobilization variables, the deposit to loan ratio, deposit to total asset ratio, the volume of deposits, and demand deposit ratio had a significant direct impact on financial sustainability. The fixed effect regression result for interest rate spread showed that an inverse relationship existed between the interest rate spread and financial sustainability. Furthermore, according to our robust fixed effect regression results, among the control variables, the age of the institution and inflation rate affects financial sustainability. Contrary to our expectations, the number of members and the percentage of woman members were not significant. This may be attributed to the fact that some members were inactive for a long period. We suggest that RUSACCOs should focus on deposit mobilization specifically on demand deposits and keep the interest rate spread narrower to ensure their sustainability.
\end{abstract}

Keywords: deposit mobilization; financial sustainability; rural savings and credit cooperatives; Ethiopia

\section{Introduction}

Increasing institutional capital through deposit mobilization is a base for competitive performance. The speed of change and competition is making companies attempt to sustain their success into the future [1]. In order to cope with changes and stay competitive, organizations have to be concerned about their sustainability. It is for this reason that many microfinance institutions (MFIs) have increased their attention towards financial sustainability in recent years [2]. Since microfinance organizations channel funds from lenders to borrowers, they play a fundamental role in economic growth. However, their impact on economic growth is realized if the sector is sustainable. To remain financially sustainable in an increasingly competitive environment, they need to attract capital at low costs. The ability of MFIs to attract and use the capital to achieve sustainability is critical to survive and grow in an increasingly competitive business climate.

Sustainability for member-owned and controlled MFIs such as rural savings and credit cooperatives (RUSACCOs) is the ability of the institution to operate without depending on external funds to ensure the continued availability of financial services towards maximizing member economic benefits. It is all about improving the economic and social well-being of all members in a sustainable way with 
internally generated revenue to cover its costs. RUSACCOs foster local economic development by mobilizing savings, and lend these out to different persons in the same area which helps to stabilize the local economy by persuading people not to emigrate [3]. This confirms that, through policies and programs approved by their members, financially sustainable RUSACCOs work for the sustainable development of the communities in which they work and reside while focusing on member needs. By mobilizing deposits they ensure continued service to members needs and build financial strength. Hence, deposit mobilization is vital to the local economic development and is a key for financial sustainability as it can contribute to self-sustainability by providing the MFI with lower cost funds [4].

Various authors have emphasized the importance of deposit mobilization for achieving financial sustainability. The continuous mobilization of deposits enhances the MFI's sustainability and contributes significantly to institutional self-sustainability [5-7]. It is a necessary condition for institutional longevity and lasting services to the poor [8]. According to Sousa-Shields and Frankiewicz [9], deposits are the most valued form of funding as well as a stable, low-cost source of funds for small financial institutions. Deposit mobilization leads to financial self-sufficiency, which is a necessary condition for institutional sustainability, and institutional sustainability is a key to the successful provision of financial services to the poor [10].

There is a longstanding debate on the idea of inclination of MFIs to either of the dual objectives (financial sustainability or outreach). In the minds of institutionalits, MFI should give priority to financial sustainability in order to provide financial services successfully to the poor, while welfarists stress the importance of outreach to the poor [11-13]. We share the belief of the institutionalists' view that microfinance organizations need to first be financially sustainable in order to serve the poor in the context of RUSACCOs. The fifth principle of cooperatives is autonomy and independency. According to this principle, RUSACCOs are autonomous and self-help financial organizations that need to finance themselves internally from member savings, share mobilization, and retain earnings for their sustainability. This principle is also about avoiding the interference of decision on RUSACCO issues by fund owners.

MFIs need to generate enough revenues by themselves to reach more poor people in the future. The provision of financial services to the poor is based on the assumption that MFIs exist on a going concern principle to solve social problems such as poverty, unemployment, and low living standards. Being financially sustainable does not limit outreach to the poor; rather, it advances outreach [14], since the poor need to have access to financial service on a long-term basis rather than just short-term financial support [15]. Financial sustainability is necessary to reach significant numbers of poor people on a permanent basis. This allows for the continued operation of the microfinance provider and the ongoing provision of financial services to the poor [16]. Since it frees them from perpetually supporting the sector, international donors have also paid attention to the commercial prospects for microfinance [17]. Sustainability is crucial under the conditions of shrinking and inconsistent donor aid [18]. Rhyne [19] and Helms [16] also posited that sustainability was the means to the goal of outreach. This shifted our attention to focus on deposit mobilization, which is seen as a contributing factor towards operational self-sufficiency [20].

Financial sustainability is affected by the capital structure factors of MFIs and deposit mobilization is one of them. By focusing on the financial structure as a whole to see its effects on financial sustainability, previous studies have documented that, for a standard microfinance institution, it is a big challenge to achieve financial sustainability due to high transaction and information costs [21-23]. Since MFIs like RUSACCOs have low transaction costs and no information asymmetry problems, we argue that sustainability can be achieved by mobilizing deposits that lower their transaction costs. The transaction cost of RUSACCOs is lower than other financial institutions because voluntary members undertake most of the work, and this unpaid participation reduces the overhead costs. Being located in rural areas, they collect deposits at their members' doorstep, so members can easily and frequently execute transactions without incurring traveling costs. Financial risk is limited since they mobilize their own resources. Members, as owners and users of the service, share common bonds, 
which reduce information asymmetry problems. In RUSACCOs, interest rates on both savings and loans are generally better than the rates given by other financial institutions. Putting it all together with its closeness to its customers, low transaction cost, fair interest rate spread, membership homogeneity, and tax exemptions is paramount to lead RUSACCOs in achieving financial sustainability. We also argue that, besides institutional sustainability, the lending upon savings allow RUSACCOs to control their growth and avoid over indebtedness since they lend the money that is needed by their members. The closest study to this argument is [24], the authors of which identified some of the key questions that any institution should ask when getting involved with microcredit programs to avoid crises. Finally, the increased reliance on member funding counters the risk of dislocation that would be caused by the discontinuation of outside support. Therefore, the purpose of the present study was to empirically investigate the potential effect of deposit mobilization on the financial sustainability of RUSACCOs in Ethiopia.

Ethiopia has a limited number of bank branches to meet the demand of financial services to all its corners, especially in remote rural areas. Financial services are largely concentrated in urban areas and RUSACCOs serve the rural population. The country's economic growth requires a huge amount of investment and high saving that has been given high attention to encourage and develop domestic saving mobilization culture [25]. For this purpose, RUSACCOs are becoming successful in saving mobilization and building a savings culture by encouraging members to save. Considering this background, we took RUSACCOs from Ethiopia on the basis that the Ethiopian economy is characterized by smallholder subsistence farming with more than 80 percent of the population depending on agriculture for their livelihood. The lack of modern inputs and sustainable loan services are among the major problems faced by smallholder farmers to initiate and sustain production activities. RUSACCOs are believed to play a fundamental role in solving these problems by providing services that range from mobilizing local savings to making credit available on time. The provision of credit is an important tool for raising the incomes of rural populations, mainly by mobilizing resources to more productive uses. Therefore, the motive for initiating this study is that very little is known about how deposit mobilization affects the financial sustainability of RUSACCOs in Ethiopia regarding sustainable loan services.

Our study contributes to the literature in five ways: First, to the best knowledge of the researchers, no study has explicitly dealt with the potential effect of deposit mobilization on the financial sustainability of RUSACCOs. RUSACCOs not only offer loans but also mobilize savings to better serve the unmet needs of the poor. Little is known, however, about whether deposit mobilization leads RUSACCOs' to achieve financial sustainability. This is crucial for the institution to focus on internal financing to ensure its self-reliance. Second, this paper tries to link demand deposits to financial sustainability. Demand deposits enable consumption smoothing in households in the face of uneven income flow and, on the other hand, provide RUSACCOs with the funds to meet the local member credit demand and provide the institution with a stable and long-term source of self-sustaining financing. Third, since the situation in urban areas is relatively better because of the concentration of financial service providers in urban areas and more of the population in developing countries like Ethiopia are found in rural areas than in urban areas, this study focused only on rural Savings and Credit Cooperatives. This enables RUSACCOs to better target the poor by mobilizing deposits from a different economic stratum of the population to create a vibrant and self-sustaining rural financial sector. Fourth, unlike previous studies, we did not use the return on asset (ROA) as a proxy for financial sustainability to observe the effect of deposit mobilization on financial sustainability. This is because ROA basically examines sustainability regardless of the institutions' funding structure. Finally, we also added the interest rate spread (IRS) as a key factor at the institutional level. This is important because the IRS has a strong relationship with both deposit mobilization and credit delivery functions. The remainder of the paper proceeds as follows: In Section 2, we provide a literature review. This is followed by Section 3 which discusses the data and methods. In Section 4, we explore the result and discussions. Finally, Section 5 provides our conclusions and the policy implication of these results. 


\section{Literature Review}

In this section, we present both the theoretical background and empirical works related to our study.

\subsection{Theoretical Underpinnings}

Our study was guided by three theories to examine the effect of deposits mobilization on the financial sustainability of Rural Savings and Credit Cooperatives: the loanable fund theory, lifecycle theory, and institutionalist theory. The loanable fund theory (LFT) was formulated by Dennis Robertson and Bertil Ohlin and applies the law of supply and demand. According to this theory, the demand for and supply of loanable funds are the basis on which to determine the interest rates. LFT uses a classical market analysis to describe the supply, demand, and interest rates for loans in the market for loanable funds [26-32]. According to these early proponents, the supply of a loanable fund comes from the firms or individuals who want to save, and they are the lenders. The demand for loanable funds comes from the entrepreneurs or investors who want to buy capital assets (i.e., to invest), and they are the borrowers. Negotiations in the loanable market are made in terms of the real interest rate. The market interest rate is therefore determined where the demand for and supply of loanable funds are equal. This means that the loanable funds market works on the principle of equilibrium. At equilibrium, both savers and investors are the happiest possible and the interest rate spread should not be so wide that one party feels exploited. This is because, as the interest rate on loan increases, it becomes more expensive to borrow, and the demand for the loan will decrease. On the other hand, as the interest rate on savings decreases, the supply of loanable funds decreases because lower interest rate discourages net savers.

The second relevant theory is the lifecycle theory (LCT), which posits financing through the institutional lifecycle. The MIX market classifies the age of MFIs into new, young, and mature. According to LCT, MFIs are expected to be financially sustainable when they attain the age of maturity. New MFIs are not typically self-sufficient and the mature ones are usually profitable. Young MFIs are mainly operationally sustainable and at the same time, financially sustainable and profitable $[9,33,34]$.

The last and most related theory in this study was the institutionalist theory approach, which focuses mainly on the financial sustainability of microfinance institutions (MFIs). The proponent of this theory focuses and gives priorities for the institutional longevity of MFIs to deliver service to the poor in a sustainable way. Their argument comes from the fact that, unless the institution is able to sustain itself financially and cover both its operating and financing costs, it will not be able to serve the poor in the long run $[10,15,35,36]$.

\subsection{Empirical Review}

\subsubsection{Deposits Mobilization}

Deposits are the cheapest funding source and one that is easier to obtain than other forms of funds. Deposit services are important for clients, financial institutions, and local economies. For clients, it provides relatively secure deposit services that meet the demand of large numbers of poor people on an ongoing basis. For financial institutions, deposit-taking can be the key to financial sustainability. This can be possible through providing a stable means to finance a growing loan portfolio to release MFIs from external dependence and subsequently improve the sustainability of the institution. Deposits may also fuel local development by increasing the resources available for productive investment [37-39].

Rural Savings and Credit Cooperatives (RUSACCOs) are basically savings-led MFIs. Savings mobilization can help RUSACCOs expand and deepen their outreach. It is a stable source of fund. This stable funding source can expand lending operations and therefore benefit borrowers. It can contribute to self-sustainability by providing the MFI with cheaper funds than those from the interbank market [40]. Deposit collection allows MFIs to provide much needed service to more poor clients and lowers the costs of capital [41]. 


\subsubsection{Deposit Mobilization and Financial Sustainability}

RUSACCOs have three main financing structures to fund their loan portfolios: debt, equity, and deposit financing. In this review, we focused on the link between the financing structure (deposits mobilization) and financial sustainability. In RUSACCOs, members provide both the demand for and the supply of loanable funds and, subsequently, the institution intermediates between member-savers and member-borrowers [42]. Several empirical studies have observed different results regarding the relationship between the financing structure and financial sustainability. Although different empirical studies have testified to inconclusiveness, notable studies have demonstrated a link between deposit mobilization and financial sustainability.

Bogan [33] investigated the impact of capital structure on the sustainability of microfinance institutions using panel data on MFIs in Africa, East Asia, Eastern Europe, Latin America, the Middle East, and South Asia for the years 2003 and 2006. Her empirical finding showed that the size of the MFI's assets and capital structure were associated with performance. A study by Mwizarubi and Singh [43] examined the impact of the modern MFIs' capital structure variables on the MFI's financial sustainability by using quarterly time series data from 1997 to 2014 . Their findings showed that, among the MFI capital structure variables, deposit mobilization was a key to financial sustainability.

According to Kinde [44], MFIs improve their sustainability through saving mobilization. His finding also indicated that savings could expand loan portfolios, reduce loaning rates, and move towards satisfying demand. Muriu [45] used an unbalanced panel dataset comprising of 210 MFIs across 31 countries operating from 1997 to 2008 to examine the impact of financing choice on microfinance profitability. By applying GMM estimators, the results showed that a proportionally higher deposit as a ratio of total assets was associated with improved profitability, assuming that the deposits program was cost-efficient.

Using unbalanced panel data collected from 23 MFIs in East Africa from the period 2004 to 2009, Tehulu [46] found an insignificant influence of deposits on financial sustainability in East Africa. Similarly, Marwa and Aziakpono [8] used 103 Saving and Credit Cooperatives (SACCOs) with audited financial statements from Tanzania, and found a negative relationship between deposit mobilization and financial sustainability. Furthermore, Bogan [47] found a negative relationship between the deposit to asset ratio and financial sustainability. A lack of experience in deposit taking and the costs associated with transformation may be the reason for the negative relationship.

Finally, an earlier study by Yaron [48] showed that the financial ratio of the value of a rural financial institution's savings deposits to its loan portfolio and the changes in this ratio over time indicated the success of the institution in replacing donor funds with savings. Yaron [48] further indicated that a rural financial institution's success in mobilizing savings was crucial to its self-sustainability.

\subsubsection{Interest Rate Spread}

Interest rate spread is the difference between the rate the financial institution pays for deposits and the rate it charges for loans. By taking a sample period from 1995 to 2014, Agapova and McNulty [49] examined the time series and cross-sectional variations in the lending and deposit rates and the spread between the rates for developed, developing, and transition economies, respectively. Their findings indicated that low spreads between the lending rate and the deposit rate were indicative of a more efficient financial system, and a wide spread was an indicator of an inefficient financial system. A high-interest-rate spread implies that the institution is charging a high interest rate on loans, thus decreasing customer demand for loans. It also indicates that savers are paid low interest on their savings, which limits the expansion of the institution in its outreach by discouraging potential savers and reduces the possible returns on savings, hence decreasing the supply of loanable funds. This trend affects the performance of the institutions. From the minimum interest rate spread, both existing borrowers and depositors obtained the benefits of cost efficiency [50].

Interest Rates in RUSACCOs: RUSACCOs are not for profit or for charity but serve members at fair profit margins. In the minds of many, this nature of RUSACCO seems complicated. On one hand, 
members with large deposits would want high interest rates, while members with large loans want lower lending rates. On the other hand, RUSACCOs are not expected to give cheap loans to members, because, like any business organization, they should provide services to their members with a fair loan interest rate by covering their operational costs and predicting future sustainable services to members. The fact that members are owners and customers of the business and are involved in decision-making provides the financial cooperative with the advantage of creating an optimal balance between the different interests. The interest rate for lending and savings is determined by the full understanding and stronger participation of the members. First the board of directors comes up with their proposed lending and savings interest rate to the members' general assembly for discussion and approval of the interest rate. Afterward, by balancing the interests of the savers and borrowers, the fair rate is decided and approved by its members. Credit unions have bettered the market loan and deposit rates for the reason that they enjoy subsidies from sponsoring firms and the government in the form of free resources and tax exemption [51].

\subsection{Stylized Facts: Rural Savings and Credit Cooperatives in Ethiopia}

In this section, we present some stylized facts about RUSACCOs in Ethiopia. Considering the importance of savings in the investment and growth process, and the unmet demand for financial services, a number of financial institutions have been established in Ethiopia in order to widen and deepen the financial markets and improve the mobilization of rural saving. Subsequent to the financial liberalization in Ethiopia (1992) and the growing influence of the cash economy in rural areas, MFIs like RUSACCOs have become very important in savings mobilizations and the provision of microloans to members in rural areas of the country [52].

In Ethiopia, RUSACCOs have a large share of the financial services market and are a dominant source of financing for the rural sector. This sector has experienced fast growth in terms of the number of cooperatives, deposits mobilized, geographical areas covered, and members reached. They are the forerunners in delivering financial services for the poor that have usually been excluded by conventional financial institutions [53] and they basically rely on members' savings as a loanable fund [54]. RUSACCOs have a larger rural outreach than MFIs. This is because rural households prefer these institutions due to the ease of accessing these services (closeness to its customers), reasonable interest rates, and access to savings. In 2016, there were about 14,976 RUSACCOs in rural areas and 7.91 billion Ethiopian birr mobilized (\$1 USD = 27.34960 Ethiopian birr (ETB) during data collection) (Figure 1).

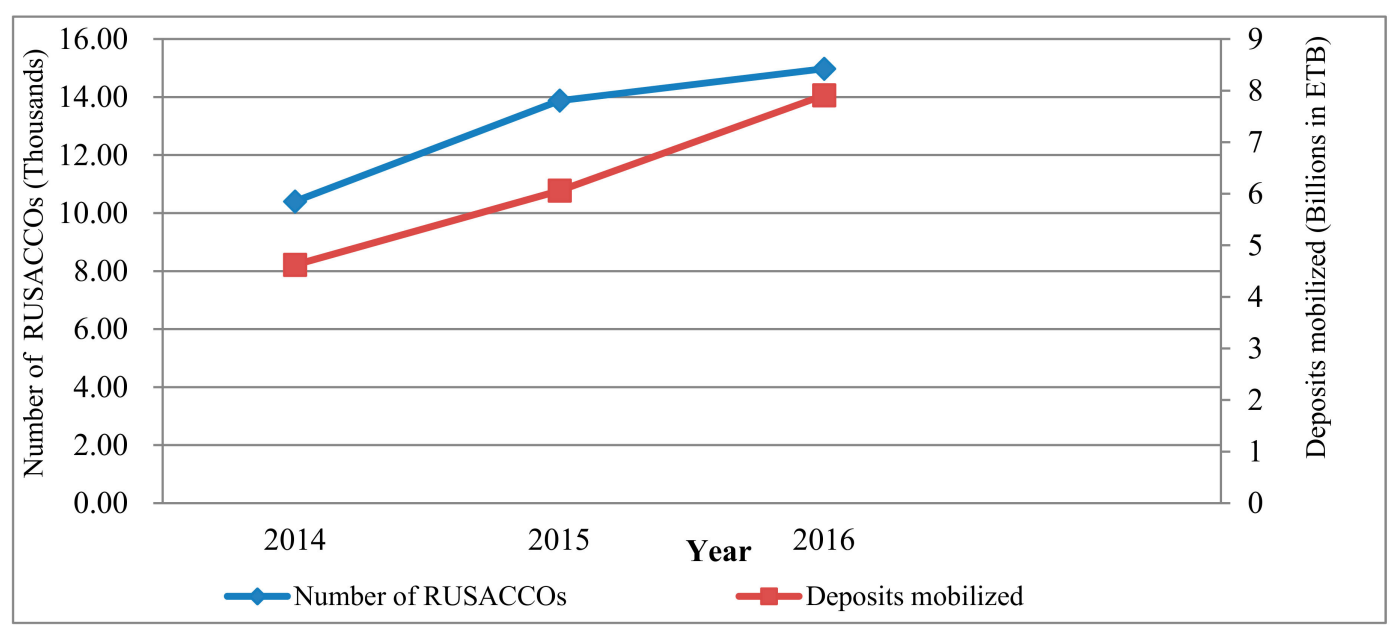

Figure 1. Growth and Savings mobilized by RUSACCOs in Ethiopia over the study period (Source: Federal Cooperative Agency (FCA) of Ethiopia, 2016). 


\subsubsection{Saving and Lending Services}

RUSACCOs are user-owned financial institutions that offer both savings and credit services to their members. Hence, members of these institutions are both net savers and net borrowers. Savings and credit cooperatives in Ethiopia are not permitted to take deposits from non-members. According to the recent Ethiopian cooperative society's proclamation no. 985/2016, part 6, article 48, subarticle 1 , a cooperative society shall not extend loan other than to its members. This proclamation further explains that the amount of annual loan to be extended by the cooperative society shall be decided by the General Assembly (all members meeting) and be included in annual plan of the society.

Members of RUSACCOs decide to save as much as they can. This decision has a direct relationship with the chance of getting the maximum amount for a loan from their RUSACCO. This in turn depends on their loan policy, which may be unique for each RUSACCO. Loans are disbursed to members according to the criteria stated in the bylaws of the RUSACCO. It may be twofold of what they have/saved in their cooperative or three times his/her savings balance. Members of RUSACCOs become eligible for loans after making regularly timed deposits, mostly an average of six months. The amount of the extended loan depends on the amount of the saved monies as well as the borrower's repayment capacity. In many cases, lending is limited by the size of the deposit resources, and may be delayed until the size of the deposit reaches a certain level. In Ethiopia, on average, a member may obtain a loan three times that of his/her savings balance [55]. A loan is secured with 100 percent collateral. The collateral for loan is the borrower's saving balance, while additional personal member-guarantors are required to secure the remaining value of the loans. The collateralized savings cannot be withdrawn until the completion of the loan repayment, which means that the guarantor has to be a non-borrower and cannot borrow until their obligation as a guarantor is settled (or transferred) [56].

A unique feature of a RUSACCO is that membership is limited to individuals (such as farmers or social organizations) who share a common bond, which is typically defined by a common employer, residential geography, religious belief, ethnic origin, or neighborhood [50]. Members are united through at least one common interest. This common bond makes members feel a greater social tie, which leads to the concept of belonging and ensures that there exists among the members a sense of identity, mutual concern, cooperation, loyalty, and trust.

\subsubsection{Technical Assistance for Cooperatives}

In Ethiopia, the Federal Cooperative Agency (FCA) provides technical advice to the regional offices and cooperative unions. The FCA and the respective regional cooperative promotion bodies are involved in promotion, organization, registration, regulation, inspection, auditing, and providing technical support to cooperatives.

According to Emana [57], the FCA works more on capacity building and on improving the networking of cooperative organizations. The Rural Financial Intermediation Program (RUFIP) is a support program designed by the FCA and funded by the African Development Bank and the International Fund for Agricultural Development (IFAD) to build the capacity of cooperatives engaged in rural savings and credit services. Figure 2 shows the organizational structure of cooperatives (including RUSACCOs) in Ethiopia for technical assistance. This is a subsidy from government bodies that ranges from providing office space to giving technical assistance. In RUSACCOs, subsidies normally come from the voluntary labor of its members, who undertake most of the activities in unpaid participation to reduce the overhead costs. 


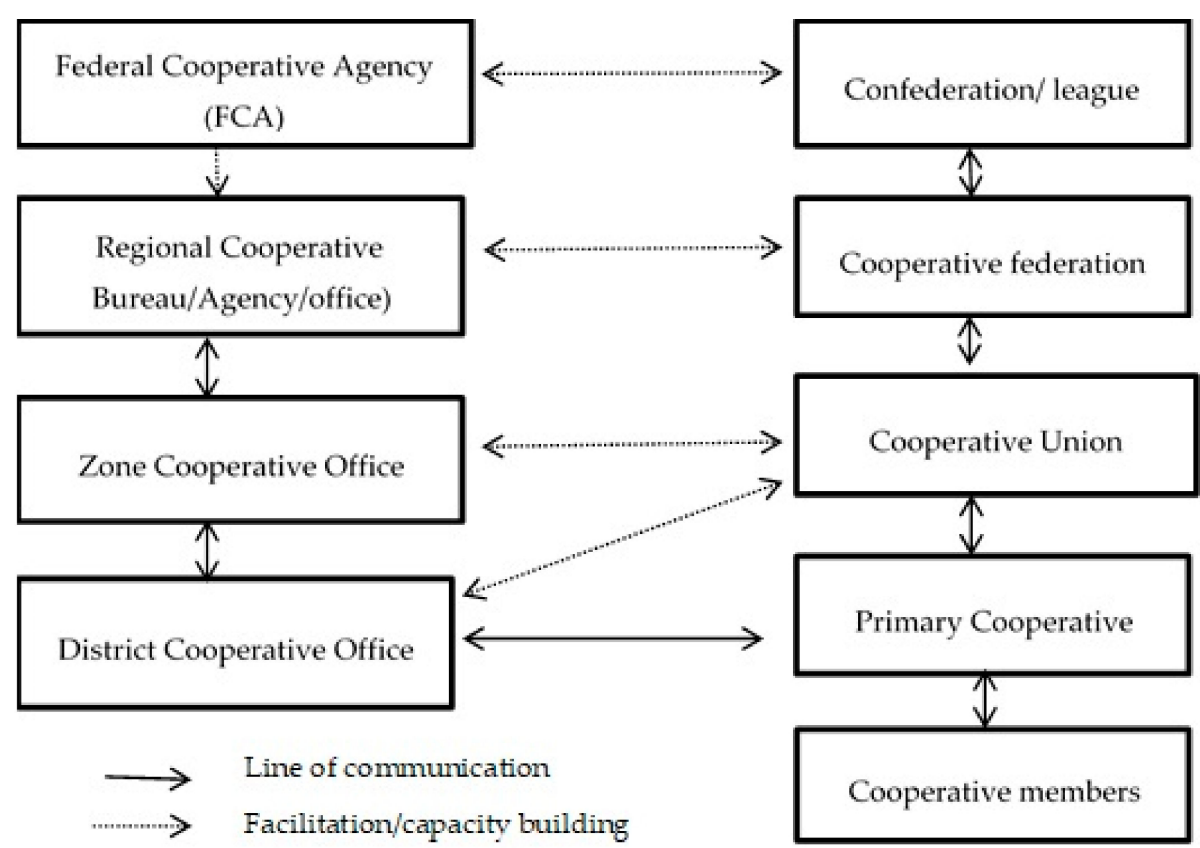

Figure 2. Organizational structure of Cooperatives in Ethiopia for technical assistance Adapted from [57].

\subsubsection{Financial Structure of RUSACCOs}

Financial structure is an institution's sources of funds (savings, shares, external credit, and institutional capital). RUSACCO Societies as financial institutions can raise their funds internally and externally. In order to avoid the interference of decision on RUSACCO issue by fund owners, and to be sustainable in the future, they need to finance themselves internally from members' savings, share mobilization, and retain earnings [57]. The internal funding options for RUSACCOs are as follows:

Savings: In RUSACCO society, the main source of money for lending to members is member savings. There are two main types of savings: compulsory savings and voluntary savings. Compulsory saving is a saving that a member is forced to save on a regular basis. That means if members fail to save on time, they will be penalized based on the saving policy of the society. It is directly related to the amount of loan that a member can access. On the other hand, voluntary savings are savings not for access to credit but for the sake of saving. Voluntary savings are characterized by convenience and return [58]. It includes demand deposit and time deposit accounts.

Share mobilization: Share is the capital of the RUSACCO society and an asset to members. It is collected from members in proportion to compulsory saving. That means every member should buy share based on the amount of compulsory saving he/she has deposited in his/her cooperative. It is a risk protecting capital and should be saved in a bank [59].

Retained earnings: According to the cooperative principles, members should receive a return on their equity as dividend and retain a portion of the profit for reserve, expansion, and social fund in the equity of the RUSACCO. In Ethiopia, 70 percent of profit is distributed as a dividend for members and the remaining amount is for reserve and expansion of the cooperative.

Deposits to Loans: This is the ratio of savings to gross loan portfolio. It measures how RUSACCO is dependent on deposits as a source of funds for extending loan to its members. It is a useful instrument to determine RUSACCOs' liquidity. Deposits and loans are the two main factors for determining the profitability of RUSACCO since it lends to members to earn interest income. Saving is collected from members in order to lend to members. Therefore, the ratio of deposits to gross loan portfolio is very important. 
Deposits to total assets: This is the ratio of savings to total assets. For deposit-taking institutions, the deposits to asset ratio measures the relative portion of the MFI's total assets that is funded by deposits and gives an informed analysis of the role of deposits as a funding source [45]. From the perspective of MFIs, the deposits to asset ratio shows the relative portion of the MFI's total assets that is funded by deposits and gives a cognizant analysis of the role of deposits as a funding source [60].

Demand deposit ratio: This is the ratio of demand deposits to total deposits. Compulsory savings may not provide sufficient volume to fund loan portfolios. RUSACCOs need to offer voluntary products. A higher ratio of demand deposits to total deposits is necessary to satisfy their member credit need. Voluntary savings are fundamental to sustainable economic development and the most frequent of source of funding [7].

External fund mobilization options for RUSACCOs include government, NGO funds, borrowing from banks, MFIs, deposits by non-member individuals, associations, and community organizations.

\subsubsection{Revenues and Expenses of RUSACCOs}

The most basic function of RUSACCO as financial intermediary is bringing savers and borrowers together in a system that enables them to pool their money as savings and shares, and after capturing the fund, transform it into loans by calculating all of the costs of doing this business to make profitable to both parties (the RUSACCO and its members) [57].

Revenues: The source of capital for a financial cooperative is retained profits added to reserves, and the main source of money for lending to members is member savings [3]. Lending to members constitutes the main source of income. Savings is a source to the RUSACCO society because it lends to members with interest. This loan interest income is the main source of income of the RUSACCO society [57]. The other revenues of RUSACCO include membership fees, service charges, and commission. Interest income is the amount of money received from borrowers (excluding principal), stated as a percentage of the loan amount. Service charges represent fees charged to clients for loan disbursement and other services associated with the loan and savings activities.

Expenses: Interest on deposit and dividends are the main financial costs of RUSACCOs. Interest on deposit is the amount of interest paid to depositors, and dividends are paid on members' shares. Other operational costs but not limited to this includes stationery costs, transportation, electricity, depreciation cost, and per diems.

\section{Data and Methods}

\subsection{Data Sources and Variables Description}

In this study, we used the manually collected annually audited balance sheet and income statement data of RUSACCOs from Ethiopia. In Ethiopia, audit and inspection results are kept in the office of the appropriate authority and the cooperative office in an easily accessible and visible manner to any person (Federal Democratic Republic of Ethiopia: Proclamation No. 985/2016). The first author collected data from August to November 2017 with the help of cooperative experts in Ethiopia during his return home. First, we obtained the lists of RUSACCOs from regional cooperative promotion bureaus. Using the available list of RUSACCOs from two regional states of the country (Oromia and Benishangul Gumuz), 166 sample cooperatives were selected on the basis of the availability of well documented and audited accounts of a society for a continuous period of three years from 2014 to 2016. Accordingly, to be included in the sample, a RUSACCO had to have had well documented reports that were relatively accessible, and have audited financial statements for three consecutive years. Lastly, we collected data from each auditing and inspection departments of the cooperatives. These departments are responsible for preparing the audit reports and other supportive official documents annually.

A macroeconomic variable like inflation was collected from the World Bank's World Development Indicators (WDI) (http:/ / data.worldbank.org/indicator) database for Ethiopia over the same period. 
The data related to the institutional characteristics of the RUSACCOs were also obtained from individual institutions as reported in their annual financial reports and audited financial statements.

\subsection{Variable Selection}

The main function of RUSACCO is intermediating deposits into loans between net saver members and net borrower members. The selection of variables for our study was based on the dual objectives of RUSACCOs: outreach and a sustainability framework. According to these dual objectives, the RUSACCOs are assumed to provide funds to net borrowers by collecting from net savers, diversifying institutional income, increasing the number of members, and developing women's participation (the number of woman members).

\subsubsection{Dependent Variable}

In this study, we investigated the effect of deposit mobilization on the financial sustainability of RUSACCOs in Ethiopia. Thus, the dependent variable was financial sustainability. Using an institutionalist view, we used the operational self-sufficiency (OSS) as a proxy for financial sustainability. OSS is the most basic measure of the financial sustainability of an MFI [61]. It measures an institution's ability to generate sufficient revenue to cover its costs. It is a MIX Market standard indicator for financial performance and has been used as a proxy for financial sustainability in various studies $[8,33,48,53,61-64]$. Achieving above $100 \%$ of OSS indicates that the institution is earning sufficient revenue from its operations to cover its costs.

The other commonly used measures of sustainability in the literature are financial self-sufficiency (FSS) and return on assets (ROA). In this study, we applied OSS over FSS because FSS is a subsidy-adjusted indicator often used by donor-funded microfinance nongovernmental organizations (NGOs) [65]. In our case, the RUSACCOs were member-owned and controlled organizations. RUSACCOs use three main financing structures as a source to fund their activities: debt, equity, and deposits. Since our study focused on deposit mobilization, we did not use the return on assets (ROA) ratio as a proxy for financial sustainability, as the ratio does not evaluate the source of the asset base whether it is through debt, equity, or deposits. It basically assesses performance regardless of the institutions' funding structure [66].

\subsubsection{Key Independent Variables}

Since this study aimed at investing the effect of deposit mobilization on financial sustainability, we used deposit mobilization variables as the key independent variables. As shown in Table 1, deposit to loan ratio, the deposit to total asset ratio, the volume of deposits, and the demand deposit ratio variables were taken from the MIX Market standard indicators for financing structure (deposit mobilization). Furthermore, we included the interest rate spread (IRS) as a key independent variable.

\subsubsection{Control Variables}

In order to avoid the possibility of obtaining bias estimations due to the omission of relevant variables, we included control variables. Hence, institutional characteristics and macroeconomic variables were controlled. The institutional characteristics control variables included the number of members (NAM), the percentage of woman members (PWM), and the age of the institution (AGEI). Inflation rate (INFL) was used to control for the impact of macroeconomic indicators on financial sustainability. 
Table 1. Description of the variables.

\begin{tabular}{|c|c|c|c|c|}
\hline Category & Variable & $\begin{array}{l}\text { Variable } \\
\text { Code }\end{array}$ & Descriptions & Expected Sign \\
\hline Dependent Variable: & $\begin{array}{c}\text { Financial } \\
\text { Sustainability }\end{array}$ & OSS & $\begin{array}{l}\text { Operating income to operating } \\
\text { expenses }\end{array}$ & na \\
\hline \multirow{5}{*}{$\begin{array}{l}\text { Key Independent } \\
\text { variables: }\end{array}$} & Interest rate spread & IRS & $\begin{array}{c}\text { (Interest received/all } \\
\text { interest-bearing assets) - (Interest } \\
\text { paid/interest earning liabilities) } \\
\times 100\end{array}$ & - \\
\hline & Deposits to loans & DTL & $\begin{array}{l}\text { Total deposits compared to the } \\
\text { gross loan portfolio }\end{array}$ & + \\
\hline & $\begin{array}{l}\text { Deposits to total } \\
\text { assets }\end{array}$ & DTTA & $\begin{array}{l}\text { Total deposits compared to total } \\
\text { assets }\end{array}$ & + \\
\hline & $\begin{array}{l}\text { Demand deposit } \\
\text { ratio }\end{array}$ & DDR & $\begin{array}{c}\text { The ratio of demand deposits to } \\
\text { total deposits in a particular } \\
\text { RUSACCO }\end{array}$ & + \\
\hline & Volume of deposits & VD & $\begin{array}{c}\text { The total amount of deposits } \\
\text { mobilized by a particular } \\
\text { cooperative in Ethiopian birr (ETB) }\end{array}$ & + \\
\hline \multirow{3}{*}{$\begin{array}{l}\text { Institutional characteristics } \\
\text { control variables: }\end{array}$} & $\begin{array}{l}\text { Number of } \\
\text { members }\end{array}$ & NAM & Number of RUSACCOs members & + \\
\hline & $\begin{array}{c}\text { Percentage of } \\
\text { woman members }\end{array}$ & PWM & $\begin{array}{l}\text { Number of woman members to } \\
\text { total members }\end{array}$ & + \\
\hline & Age of RUSACCOs & AGEI & $\begin{array}{l}\text { Number of years the RUSACCO has } \\
\text { been in operation }\end{array}$ & + \\
\hline $\begin{array}{l}\text { Macroeconomic indicator } \\
\text { control variable: }\end{array}$ & Inflation Rate & INFL & Annual Inflation Rate (\%) & - \\
\hline
\end{tabular}

\subsection{Empirical Model}

We used a balanced panel regression analysis model with a three-year time period and 166 RUSACCOs. The panel data comprised of repeated measures of one or more variables on one or more firms [67]. Unlike cross-sectional data, panel data are good for testing the impact of deposit mobilization on the financial sustainability of rural savings and credit cooperatives over time. Cross-sectional data mostly cannot accurately test the impact of economic activities' over time [68]. The panel data fixed effects model was selected for use after testing for specification bias using the Hausman test. The general form of panel regression analysis can be specified as [69].

$$
\gamma_{i t}=\beta_{1} x_{i t 1}+\beta_{2} x_{i t 2} \ldots+\beta_{k} x_{i t k}+\alpha_{i}+\mu_{i}
$$

where $\gamma_{i t}$ is the value of the dependent variable for RUSACCO $i$ at time $t, i=1 \ldots N$ and $t=1 \ldots T$; $\alpha_{i}$ is the intercept term or individual effect, $\beta_{j}$ are the parameters to be estimated on the independent variables, $\chi_{i t}$ is a vector of observations on the explanatory variables in period $t$ for unit $i$, and $\mu_{i}$ is the error term. Our final empirical model for the fixed effects estimators can then be given as Equation (2) below:

$$
\begin{aligned}
\text { OSS }_{\text {it }}=\alpha_{\mathrm{i}}+\beta_{1}(\mathrm{IRS})_{\mathrm{it}} & +\beta_{2}(\mathrm{DTL})_{\mathrm{it}}+\beta_{3}(\mathrm{DTTA})_{\mathrm{it}}+\beta_{4}(\mathrm{DDR})_{\mathrm{it}}+\beta_{5}(\operatorname{lnVD})_{\mathrm{it}}+\beta_{6}(\operatorname{lnNAM})_{\mathrm{it}} \\
& +\beta_{7}(\mathrm{PWM})_{\mathrm{it}}+\beta_{8}(\operatorname{lnAGEI})_{\mathrm{it}}+\beta_{9}(\mathrm{INFL})_{\mathrm{t}}+\epsilon_{\mathrm{it}}
\end{aligned}
$$

where $\alpha$-is the intercept, and $\beta_{1}, \beta_{2}, \beta_{3}, \beta_{4}, \beta_{5}, \beta_{6}, \beta_{7}, \beta_{8}$ and $\beta_{9}$ are the coefficients for each independent variable in the model.

\subsection{Model Specification Tests}

Model specification involves the proper determination of relationships and parameters in the model [70]. Using various estimation techniques through rational argumentation relevant to 
the properties of the different models, we estimated the coefficients to select the best technique. Table A1 shows the estimation results based on techniques such as the ordinary least square (OLS), pooled feasible general least square (PFGLS), between estimator (BE), random effects (RE), and fixed effects (FE) models. A fixed effect was been selected as the best technique. The general procedure we used to search for the best model is composed of five steps.

First, if the pooled was preferred to the fixed effects model, we estimated the pooled and fixed effects models by using the Chow test. The results supported the use of the fixed effects model (Table A2). Second, we also conducted the Breusch Pagan Lagrange Multiplier for the random effect to examine whether the pooled model was preferable to the random effect model. The results supported use of the random effect model (Table A2). Third, in order to choose between the fixed effects and random effects, we conducted the Hausman test (Table 2). If the probability of the chi-square in the Hausman test output was less than 0.05 , the fixed effect was preferred; otherwise, the random effect was preferred [71]. When we ran the test, the probability of the chi-square was found to be 0.0049 , which was less than 0.05 , therefore showing that the null for independent errors of the regression was rejected in favor of the alternative, confirming the need to use the fixed effects rather than random effects. Thus, the results from the fixed effects model supported the view that deposit mobilization affected financial sustainability. Hence, this study applied the fixed effect regression model.

Table 2. Hausman fixed random test results.

\begin{tabular}{cccc}
\hline Variables & \multicolumn{3}{c}{ Coefficients } \\
\cline { 2 - 4 } & Fixed Effects (b) & Random Effects (B) & Difference (b - B) \\
\hline Interest rate spread (IRS) & -0.0301047 & -0.0311434 & 0.0010387 \\
Deposits to loans (DTL) & 0.1483213 & 0.1057206 & 0.0426007 \\
Deposits to total assets (DTTA) & 0.0066327 & 0.0046166 & 0.0020161 \\
Volume of deposits (VD) & 0.0400415 & 0.0383409 & 0.0017007 \\
Demand deposit ratio (DDR) & 0.474553 & 0.3404649 & 0.1340881 \\
Number of members (NAM) & 0.1654182 & 0.1314443 & 0.0339739 \\
Percentage of woman members (PWM) & -0.0001131 & 0.0019687 & -0.0020818 \\
Age of institution (AGEI) & 0.3297226 & 0.2682405 & 0.0614821 \\
Inflation (INFL) & -0.0422565 & -0.0400141 & -0.0022424 \\
\hline
\end{tabular}

Note: Ho: difference in coefficients not systematic; chi2 $\left.(9)=(\mathrm{b}-\mathrm{B})^{\prime}\left[\left(\mathrm{V}_{-} \mathrm{b}-\mathrm{V} \_\mathrm{B}\right){ }^{-1}\right)\right](\mathrm{b}-\mathrm{B})=23.65$; Prob. $>$ chi $2=0.0049$.

Provided that the fixed effects model is preferred to the pooled and random effects models, we also tested for autocorrelation between the error terms of the models by using the Wooldridge test for autocorrelation in the panel data. The test results showed the presence of the first-order autocorrelation in the error term in the regression models. The null hypothesis of no serial correlation was strongly rejected (Table A2). We also tested for heteroskedasticity to check the presence of constant variance among the error terms. The results showed the presence of heteroskedasticity in the regression model (Table A2). The null was homoskedasticity (or constant variance). Hence, we rejected the null and concluded heteroskedasticity. To check for stationarity in the dependent variable OSS, we used the Harris-Tzavalis unit-root test as proposed by Harris and Tzavalis [72] and is applied to data sets that are relatively short in time. The outputs from our test were ( $p$-value $=0.0006$, rho $=0.0702$, and $z=-2260)$; therefore, we rejected the null that all panels contained unit roots.

Finally, we conducted a variance inflation factor (VIF) test to examine whether multicollinearity existed between independent variables. When the variance inflation factor is greater than 10, multicollinearity is a problem for estimating the coefficients $[69,73,74]$. According to our estimation (Table A2), the highest VIF was 1.44; therefore, there was a low level of multicollinearity; as such, multicollinearity was not an issue in our estimations. We also used Pearson correlation coefficients to test for the presence of multicollinearity between the independent variables. The maximum coefficient in Table 3 was 0.398 , which shows that the pairwise correlations between the variables were not high, 
denoting that multicollinearity was not a problem. When the pairwise correlation coefficient between two regressors is in excess of 0.80 , multicollinearity is a problem [74].

Table 3. Pearson correlation coefficients.

\begin{tabular}{lccccccccc}
\hline & $\mathbf{1}$ & $\mathbf{2}$ & $\mathbf{3}$ & $\mathbf{4}$ & $\mathbf{5}$ & $\mathbf{6}$ & $\mathbf{7}$ & $\mathbf{8}$ & $\mathbf{9}$ \\
\hline IRS & 1.000 & & & & & & & & \\
DTL & 0.278 & 1.000 & & & & & & & \\
DTTA & -0.266 & 0.263 & 1.000 & & & & & & \\
VD & -0.157 & 0.077 & 0.147 & 1.000 & & & & \\
DDR & -0.009 & -0.058 & -0.070 & 0.012 & 1.000 & & & \\
NAM & -0.247 & -0.152 & -0.019 & 0.184 & -0.073 & 1.000 & & & \\
PWM & -0.016 & -0.041 & -0.059 & -0.072 & 0.160 & 0.133 & 1.000 & & \\
AGEI & -0.259 & 0.084 & 0.398 & 0.210 & -0.030 & 0.303 & 0.129 & 1.000 & \\
INFL & 0.019 & 0.002 & -0.048 & 0.026 & 0.011 & 0.096 & -0.007 & 0.047 & 1.000 \\
\hline
\end{tabular}

\section{Empirical Results and Discussion}

\subsection{Descriptive Statistics}

The panel data sets of this study included one dependent variable (operational self-sufficiency), and nine independent variables (interest rate spread, deposit to loan ratio, deposit to total asset ratio, the volume of deposits, the ratio of demand deposits, the number of members, the percentage of woman members, the age of the institution, and inflation rate). Descriptive statistics are presented in Table 4 .

Table 4. Descriptive statistics.

\begin{tabular}{cccccc}
\hline Variable & Obs. & Mean & Std. Dev. & Min & Max \\
\hline OSS & 498 & 2.669 & 2.327 & 0.020 & 11.99 \\
IRS & 498 & 10.01 & 8.489 & 0.290 & 31.86 \\
DTL & 498 & 1.194 & 1.527 & 0.016 & 10.66 \\
DTTA & 498 & 47.19 & 31.72 & 0.037 & 122.9 \\
VD & 498 & 9.576 & 2.974 & 5.298 & 66.89 \\
DDR & 498 & 0.040 & 0.208 & 0.000 & 3.069 \\
NAM & 498 & 4.192 & 0.875 & 2.303 & 6.321 \\
PWM & 498 & 54.41 & 36.89 & 0.000 & 100.0 \\
AGEI & 498 & 1.044 & 0.671 & 0.000 & 2.485 \\
INFL & 498 & 8.263 & 1.322 & 7.270 & 10.13 \\
\hline
\end{tabular}

This section summarizes the descriptive statistics of the variables used in this paper. The results of the descriptive statistics in Table 4 show that, on average, RUSACCOs have operational self-sufficiency (OSS) with a mean value of 2.67, measured as the ratio of financial revenue to expenses, indicating that the RUSACCOs in the sample were operationally self-sufficient. The figure for this variable was above the standard; therefore, the financial revenues of the RUSACCOs were sufficient to cover their operating expenses. For operational self-sufficiency, a value above one indicates that the institution is covering its costs from its operating revenues. The standard deviation for OSS was 2.33 , an indication of the existence of dispersion in the operational self-sufficiency of the RUSACCOs studied.

In Table 4, interest rate spread (IRS) indicated that RUSACCOs in Ethiopia earned, on average, $10 \%$ IRS with a minimum of $0.29 \%$ and a maximum of $31.86 \%$. This indicates that the more financially sustainable RUSACCOs earned $0.29 \%$, and the less financially sustainable ones earned a $31.86 \%$ interest rate spread. It also showed that cooperatives that were operationally self-sufficient had a low spread between the loan and deposit rates. The standard deviation of $2.33 \%$ indicated that the spread variation from its mean was small. Likewise, Table 4 showed that the deposit loan ratio had a value of 1.19, which demonstrates that RUSACCOs in Ethiopia, on average, used 1.19 deposits as a source of 
funds for loan portfolios to achieve operational self-sufficiency. A ratio of 1 means that the institution fully financed its loans from its own internally mobilized deposits, without depending on external borrowing and subsidies.

The value of the mean for the deposit to total asset (DTTA) ratio was 47.20 and showed that, on average, 47.20 of the RUSACCOs' assets were financed by internally mobilized deposits. According to Table 4, RUSACCOs in Ethiopia, on average, have 9.58 volumes of deposits (VD) to fund their loan portfolios. Furthermore, Table 4 illustrates that the mean for the demand deposit ratio (DDR) was 0.04 , which indicates that members of RUSACCOs in Ethiopia only save compulsory savings and that there were low voluntary savings products in the country.

Finally, for the control variables such as the number of members (NAM), the percentage of woman members (PWM), the age of institution (AGEI), and the inflation rate (INFL), we observed mean values of 4.19,54.41, 1.04, and 8.26, respectively, and standard deviations of $0.88,36.88,0.67$, and 1.32 , respectively. The average mean of 54.41 for the percentages of woman members (PWM) showed high improvements in the participation of women in rural savings and credit cooperatives in Ethiopia over the study period.

\subsection{Trend Analysis of RUSACCOs' Financial Performance}

Table 5 indicates trends of financial performance by sample RUSACCOs over the study periods. The trend of the average ratio for operational self-sufficiency (OSS) from Table 5 was $2.273,2.628$, and 3.106, respectively, which showed improvements over the years. OSS measured how the RUSACCO generated sufficient revenue from operations to cover its operating and financing costs. It was calculated by dividing financial revenue to operating expenses plus financial expenses. The highest OSS was achieved in 2016, which were 3.106 (310.6\%). According to MIX Market, the break-even point is $1(100 \%)$. For all years, RUSACCOs achieved an OSS ratio above break-even points.

Table 5. Trends of RUSACCOs' financial performance over the study period.

\begin{tabular}{ccccc}
\hline & $\mathbf{2 0 1 4}$ & $\mathbf{2 0 1 5}$ & $\mathbf{2 0 1 6}$ & Average \\
\hline Operational self-sufficiency ratio, average & 2.273 & 2.628 & 3.106 & 2.669 \\
Interest rate spread, average & $14.25 \%$ & $10.05 \%$ & $5.72 \%$ & 10.01 \\
Deposit to loan ratio, average & 1.233 & 1.195 & 1.153 & 1.194 \\
Deposit to total asset ratio, average & 34.98 & 45.62 & 61.01 & 47.20 \\
Demand deposit ratio, average & 0.051 & 0.043 & 0.027 & 0.040 \\
Number of members & 9704 & 17,784 & 19,717 & 15,735 \\
\% woman members, average & $46.91 \%$ & $54.37 \%$ & $61.94 \%$ & 54.41 \\
Age of the institution(years), average & 2.55 & 3.55 & 4.46 & 3.52 \\
Total volume of deposits, ETB & $4,956,328.26$ & $7,856,587.94$ & $17,410,084.43$ & $10,074,333.54$ \\
Total loans disbursed, ETB & $6,234,177.12$ & $13,022,585.3$ & $6,234,177.12$ & $8,496,979.85$ \\
Total incomes, ETB & $1,239,969.20$ & $4,635,423.25$ & $4,168,965$ & $3,348,119.14$ \\
Total expenses, ETB & $414,607.78$ & $1,474,578.37$ & $1,688,345.36$ & $1,192,510.50$ \\
Total assets, ETB & $14,721,601.21$ & $54,774,004.16$ & $32,134,945.23$ & $33,876,850.20$ \\
\hline
\end{tabular}

( $\$ 1$ USD = 27.34960 Ethiopian birr (ETB) during data collection).

According to Table 5, the average of the interest rate spread narrowed over the years, which indicated RUSACCOs were charging fair interest rates on both saving and loans over the years. In Ethiopia, the cooperative society's proclamation no. 985/2016, part 6, article 48, subarticle 2, states that any cooperative society for the money it lends shall prescribe the interest rate in its by-laws based on the special resolution of the General Assembly. Based on this proclamation, different RUSACCOs in the country have their own by-laws, which state different interest rate levels on both lending and savings. In our sample RUSACCOs, the average yearly interest rate level charged on lending ranged from 9 to $12.5 \%$, and the average interest rate level paid on savings ranged from 3 to $6.5 \%$. 
The results for the average of deposit to total asset ratio, the volume of deposit, the number of members, the percentage of woman members, and the age of the institution increased over the years. The average for the deposit to loan ratio was high in 2014 and decreased in 2015 and 2016. Average demand deposit ratio for the RUSACCOs was also decreased for all three years. From Table 5, the average total volume of savings $(10,074,333.54 \mathrm{ETB})$ was greater than the average of total loans $(8,496,979.85 \mathrm{ETB})$ disbursed over the study period. Table 5 shows that the deposit to loan ratio declined in 2015 and 2016, while the deposit to total asset ratio increased in the same year. The average percentage of woman members was 54.41 percent across the sample, and increased over the study periods. Finally, Table 5 revealed that the average total incomes $(3,348,119.14$ ETB) generated by sample RUSACCOs exceeded the average total expenses (1,192,510.50 ETB) over the study period. This shows that RUSACCOs covered their operatizing expenses by internally generated revenues.

\subsection{Fixed Effects Regression Results}

The robust fixed effects models summarized in Table 6 showed that all key and two control independent variables (age of institution and inflation) were statistically significant and the other two control variables were not significant. Since our model suffered from both autocorrelation and heteroskedasticity problems (see Section 3.3), we employed heteroskedasticity-robust standard errors to estimate the coefficients of the variables as correction measures.

Table 6. Robust fixed effects estimation.

\begin{tabular}{ccc}
\hline \multicolumn{2}{c}{ Dependent Variable: Operational Self-sufficiency (OSS) } \\
\hline Independent Variables & Coefficient & Standard Error (Robust) \\
\hline Interest rate spread (IRS) & $-0.0301^{* * *}$ & 0.0106 \\
Deposit to loan ratio (DTL) & $0.148^{* *}$ & 0.0745 \\
Deposit to total asset ratio (DTTA) & $0.00663^{*}$ & 0.00372 \\
Volume of deposits (VD) & $0.0400^{* * *}$ & 0.0136 \\
Demand deposit ratio (DDR) & $0.475^{* * *}$ & 0.144 \\
Number of members (NAM) & 0.165 & 0.175 \\
Percentage of woman members (PWM) & -0.000113 & 0.00495 \\
Age of institution (AGEI) & $0.330^{* *}$ & 0.148 \\
Inflation rate (INFL) & $-0.0423^{*}$ & 0.0215 \\
cons & $1.395^{*}$ & 0.707 \\
\hline Observations & 498 & \\
No. of groups & 166 & \\
R-square: within & 0.2490 & \\
F(9,165) & 9.51 & \\
Prob. $>\mathrm{F}$ & 0.0000 & \\
sigma_u & 2.2967485 & \\
sigma_e & 0.87460113 & \\
rho & ${ }^{*} p<0.10, * * p<0.05, * * * p<0.01$. \\
\end{tabular}

Rho is the proportion of variation due to the individual specific term. From the above table, a large proportion $(87.33 \%)$ was explained by the individual specific terms and the rest due to idiosyncratic errors. The R-square showed that the fixed effects estimator could explain $24.90 \%$ within variations. The fixed effects regression results presented in Table 6 show that the interest rate spread (IRS) negatively influences the financial sustainability of RUSACCOs in Ethiopia as it was statistically significant at $1 \%$. This means that a unit increase in the interest rate spread within RUSACCOs over time will lead to a $3.01 \%$ decrease in the operational self-sufficiency of the RUSACCOs. A wide interest rate spread has two implications for financial institutions. Both affect the sustainability of the institution. The first is that borrowers are charged a high interest on loans, thus decreasing their demand for loanable funds. As the demand for loans decrease, the institution loses interest income from the loan. The second implication is that savers are paid low interest rates on their savings. 
The implication of the negative relationship between interest rate spread and financial sustainability is that the wide interest rate spread discourages savers, which reduces the loanable funds of the institutions from which they can earn interest income for their sustainability. Loanable fund theory supports this finding. According to loanable fund theory, interest rate spread should not be very wide where one party feels exploited [26]. Both savers and investors are at their happiest possible when at an equilibrium level. This shows that the market interest rate is determined by the intersection between the supply and demand for loanable funds [75].

Savings constitute the most important source of the supply of loanable funds for financial cooperatives. It collects them from its net saver members to lend to its net borrower members with interest. This loan interest is the main source of income of RUSACCO societies. The negative relationship was consistent with Agapova and McNulty [49], who found a negative relationship between the interest rate spread and traditional balance sheet measures of financial intermediation. High spread implies low efficiency in intermediating financial services.

The deposit to loan ratio was significant at $5 \%$ and positively related to financial sustainability. The results showed that a unit increase in deposit to loan ratio within RUSACCOs over time led to an increase in operational self-sufficiency by $14.80 \%$ in RUSACCOs. A high ratio implies that the institution is relying on its own deposits to make loans to its members without outside borrowing. The higher the ratio, the greater the RUSACCOs' ability to fund its loan portfolio from its deposits and enhances operational self-sufficiency. Another implication of this finding is that the institution might have enough liquidity to cover any unforeseen funding requirements. An earlier study by Yaron [48] supports this positive relationship. The changes in deposit to loan ratio over time indicate how the institution is successful in replacing external funding with its own savings. In a nutshell, a high ratio implies that the institution is dependent on deposits as a source of funds for loan portfolios from which it earns interest income. Fewer ratios mean fewer funds to loan to borrowers and reduce the opportunity to make revenue through interest earnings on loans.

Furthermore, this study found the deposit to total asset ratio to be statistically significant in determining the financial sustainability of RUSACCOs and had a positive and statistically significant coefficient at $10 \%$. As the deposit to asset ratio changes within RUSACCOs over time, operational self-sufficiency also changes. This shows that a unit change in the deposit to asset ratio leads to a $0.663 \%$ increase in the operational self-sufficiency of RUSACCOs. This finding is similar to one of Mwangi and Muturi [60], who found the deposit to asset ratio to be statistically significant in determining the financial sustainability of MFIs in Kenya. However, Bogan [33] found a negative relationship between the deposit to asset ratio and financial sustainability. This may be attributed to the lack of experience in deposit mobilization.

The coefficient of the log of the volume of deposits (VD) revealed a positive and significant relationship with operational self-sufficiency at $1 \%$. A unit increase in the volume of savings within RUSACCOs over time leads to an increase in operational self-sufficiency by $4 \%$, and this result supports the idea that the entire business of savings mobilization hinges on high volume and low costs. The high volume of savings is integral to sustainability [7]. This indicates that the more deposits a RUSACCO is able to attract, the more funds are available to lend to members. By mobilizing a large volume, financial institutions reduce costs and enjoy economies of scale. The higher the volume, the greater the probability of granting loans to borrowers and then by matching the incoming deposits with the outgoing loans, the higher the interest income from the loan for their sustainability. Large volumes of deposits provide a stable means to finance a growing loan portfolio and contribute to self-sustainability by providing the institution with cheaper funds.

The demand deposit ratio is positively related and statistically significant at $1 \%$. A unit increase in the demand deposit ratio within RUSACCOs over time will lead to a $47.5 \%$ increase in the sustainability of the RUSACCOs, which is contrary to Cozarenco, Hudon [76], who noted that taking voluntary savings was not related to financial performance. RUSACCOs are basically savings-led organizations and mobilize large numbers of small voluntary (demand) savings. They offer two savings products: 
compulsory and voluntary savings. Compulsory savings do not provide sufficient volume to fund loan portfolios [7]. This limits the loanable fund amount from which RUSACCOs obtain interest income and limits the scope of operation, so then the continuity of the institution to provide financial services for their members on a sustainable basis will be in question.

In our study, the potential RUSACCOs members were farmers who only receive income once a year. Voluntary (demand) savings are very important to farmers who have a seasonal income. This is because farmers do not have a regular income to save regularly, instead if a voluntary savings product is available, they save large amount as voluntary savings during harvesting time and transfer funds monthly to their compulsory saving accounts [59]. This ensures a regular cash flow for the institution, which leads to operational self-sufficiency.

Contrary to our expectations, a log of the number of members was not significant, but was positively related to operational self-sufficiency; this may be attributed to the fact that some members are inactive for long periods of time, especially in savings activities. The observed positive coefficient for the number of members indicated that as the number of members' increased the volume of deposits also increases, which leads to the cooperatives having more liquidity to fund their loan portfolios from which they obtain interest income for operational self-sufficiency. Our findings were not in line with the previous study that argued that large memberships make rural cooperatives financially strong by increasing their capital base [54]. Boehe and Barin Cruz [77] also noted that high membership numbers would suggest that the microfinance cooperative can generate economies of scale.

Surprisingly, the percentage of woman members (PWM) was not significant and was negatively related to operational self-sufficiency. This might be because women still have less power in decisions regarding financial undertakings and are forced into financial dependency on their husbands in Ethiopia. Contrary to our finding, Abdullah and Quayes [78] found a positive relationship between the percentage of woman members and financial performance. On the other hand, the findings of Boehe and Barin Cruz [77] showed that there was a negative relationship. Since men tend to have more formal education than women in many developing country contexts, this may also account for the gender disparity [17].

The variable age of the RUSACCO, as measured by the natural logarithm of the cooperatives' age was significant at $5 \%$ and positively related to operational self-sufficiency. The regression results showed that an increase in the age of RUSACCOs over time resulted in a 33\% increase in their operational self-sufficiency, thus verifying that mature (MIX Market classifies age of the financial institutions as new (0-4), young (5-8), and mature (>8) years) institutions are more likely to be operationally self-sufficient than younger institutions. This implies that the longer the RUSACCO has been in existence, the more experience it gains in deposit mobilization. It accumulates a sufficiently adequate capital that improves operational self-sufficiency over a period of years. This finding was consistent with the expectations of the life cycle theory, which posits that the sources of financing are related to institutional development [33]. As the age of the institution increases, they gain more experience and therefore have better operational self-sufficiency. Our results are consistent with those of Mahinda and Jacob [34], who found that older MFIs performed better than younger ones in terms of achieving financial goals. Contrary to our finding, Gutierrez-Goiria and San-Jose [79] found that the oldest MFIs were less efficient in both economic and social terms in comparison with the young one.

Lastly, as expected, inflation was significant and negatively related to operational self-sufficiency, showing that inflation negatively affects both the institution and its members. High inflation rates could diminish the capacity of individuals to save by spending more of their income on consumption, and this reduces an institution's ability to cover its costs. In our findings, when the inflation rate increased by $1 \%$, all other things being equal, the operational self-sufficiency of the RUSACCOs decreased by $4.23 \%$. 


\section{Conclusions}

The primary motive for mobilizing savings lies in lower cost of capital compared to other sources. For RUSACCOs, deposit mobilization is the most stable and affordable funding source that ensures their financial sustainability. Sustainable rural financial institutions can fill the gap left by other financial institutions in the provision of financial services to the remote rural areas. Financially sustainable RUSACCOs work for the sustainable development of communities in which they work and reside while focusing on member needs. This has an implication for policy makers for designing appropriate saving products to ensure institutional sustainability which is crucial for appropriate financial intermediation services between savers and borrowers. An appropriate saving product allows financial institutions to generate low cost deposits to rise sustainable funding for lending activities.

This study aimed to investigate the potential effect of deposit mobilization on the financial sustainability of rural savings and credit cooperatives (RUSACCOs) in Ethiopia. Using a robust fixed effects regression approach and panel data of 166 RUSACCOs over the 2014-2016 period, we found that deposit mobilization variables (interest rate spread, deposit to loan ratio, deposit to total asset ratio, volume of deposits, and demand deposit ratio), except for interest rate spread (IRS), had a significant direct impact on financial sustainability. The results of the fixed effect regression for interest rate spread indicated that there is an inverse relationship between the interest rate spread and operational self-sufficiency. The implication of this is that, when the spread is wide, it discourages net savers and decreases the income of the institution by reducing loanable funds. Since RUSACCOs are not for profit or for charity but serve members at fair profit margins, they need to keep their interest rate spread low in order to achieve financial sustainability to provide financial service in a sustainable way.

Furthermore, according to our robust fixed effect regression results, among the control variables, the age of the institution and inflation rate affected financial sustainability. In line with the life cycle theory, the age of the institution affects financial sustainability. On the other hand, inflation negatively affects financial sustainability indicating that members spend their money on consumption and start dissaving, which means no loanable fund for the institution from which it gains interest income. Contrary to our expectations, the number of members and the percentage of woman members were not significant. This may be attributed to the fact that some members are inactive for a long period of time. We suggest that further research be conducted by taking an active number of members only for the long panel data to see the effect on the financial sustainability of financial institutions.

From the findings of the study, we can conclude that interest rate spread, deposit to loan ratio, deposit to total asset ratio, the volume of deposits, demand deposit ratio, the age of institution, and inflation are vibrant in determining the financial sustainability of RUSACCOs in Ethiopia. Therefore, the study recommends that RUSACCOs should focus on deposit mobilization, specifically on demand deposit (voluntary savings), to ensure their sustainability so that many farmers can use their services to save from their seasonal incomes. Furthermore, we recommend that there is a need for RUSACCOs to keep their interest rate spread narrower to attract more loanable funds and encourage the demand for loans, which would help the institution achieve operational self-sufficiency.

Finally, this study is not without limitations. First, the study was limited to three years of data and 166 RUSACCOs. Future studies may focus on a longer period of panel data with a larger sample size. Second, this paper attempted to link deposit mobilization to financial sustainability. However, it does not seem to tell the entire story with respect to the financial structure of all RUSACCOs. Other financial structures such as mobilizing shares and retaining earnings may have an effect on financial sustainability. Additional studies could include these financial structures to determine the relationship between the financial structure of cooperatives and their sustainability.

Author Contributions: The authors contributed equally to this paper. All the authors read and approved the final manuscript.

Funding: This research was funded by Chinese Ministry of Agriculture (2016-X10) and NAU (KYGB201802). 
Acknowledgments: The authors acknowledge the sponsorships of a project funded by the Priority Academic Program Development of Jiangsu Higher Education Institutions (PAPD) and the Agricultural Policies in East Africa and Their Impact on Agricultural Cooperation between China and East Africa (KYGB201802).

Conflicts of Interest: The authors declare no conflict of interest.

\section{Appendix A}

Table A1. Estimator comparisons for the panel data models.

\begin{tabular}{cccccc}
\hline & OLS & PFGLS & BE & RE & FE \\
\hline IRS & -0.00890 & $-0.0294^{* * *}$ & -0.00890 & $-0.0311^{* * *}$ & $-0.0301^{* * *}$ \\
& $(0.0165)$ & $(0.00858)$ & $(0.0143)$ & $(0.00990)$ & $(0.0106)$ \\
DTL & -0.0710 & $0.101^{*}$ & -0.0710 & 0.106 & $0.148^{* *}$ \\
& $(0.0678)$ & $(0.0522)$ & $(0.0775)$ & $(0.0691)$ & $(0.0745)$ \\
DTTA & -0.00109 & $0.00498^{*}$ & -0.00109 & 0.00462 & $0.00663^{*}$ \\
& $(0.00325)$ & $(0.00289)$ & $(0.00397)$ & $(0.00317)$ & $(0.00372)$ \\
VD & $0.0451^{*}$ & $0.0328^{* * *}$ & 0.0451 & $0.0383 * * *$ & $0.0400^{* * *}$ \\
& $(0.0263)$ & $(0.00875)$ & $(0.0371)$ & $(0.0143)$ & $(0.0136)$ \\
DDR & -0.255 & $0.320^{*}$ & -0.255 & $0.340 * * *$ & $0.475^{* * *}$ \\
& $(0.274)$ & $(0.166)$ & $(0.517)$ & $(0.130)$ & $(0.144)$ \\
NAM & -0.0576 & 0.151 & -0.0576 & 0.131 & 0.165 \\
& $(0.136)$ & $(0.137)$ & $(0.134)$ & $(0.146)$ & $(0.175)$ \\
PWM & 0.00279 & 0.00277 & 0.00279 & 0.00197 & -0.000113 \\
& $(0.00315)$ & $(0.00376)$ & $(0.00296)$ & $(0.00378)$ & $(0.00495)$ \\
AGEI & 0.0674 & $0.244^{*}$ & 0.0674 & $0.268 *$ & $0.330^{* *}$ \\
& $(0.162)$ & $(0.135)$ & $(0.185)$ & $(0.132)$ & $(0.148)$ \\
INFL & -0.0313 & $-0.0394^{*}$ & -0.0313 & $-0.0400 *$ & $-0.0423^{*}$ \\
& $(0.0788)$ & $(0.0217)$ & $(0.0799)$ & $(0.0218)$ & $(0.0215)$ \\
_cons & $2.751 * * *$ & $1.569^{* * *}$ & $2.751 * * *$ & $1.648^{* *}$ & $1.395^{*}$ \\
& $(0.913)$ & $(0.607)$ & $(0.922)$ & $(0.643)$ & $(0.707)$ \\
\hline N & 498 & 498 & 498 & 498 & 498 \\
R-square & 0.010 & & 0.010 & & 0.249 \\
adj. R-sq. & -0.009 & & -0.009 & & 0.235 \\
F & 0.762 & & 0.527 & & 9.509 \\
\hline
\end{tabular}

Standard errors in parentheses: ${ }^{*} p<0.10,{ }^{* *} p<0.05,{ }^{* * *} p<0.01$. OLS: Ordinary least square, PFGLS: Pooled Feasible General Least square, BE: Between Effects, RE: Random Effects, FE: Fixed Effects

Table A2. Regression assumption tests.

\begin{tabular}{|c|c|c|c|}
\hline \multicolumn{4}{|c|}{ F-Test (Fixed vs. Pooled Regression) } \\
\hline \multicolumn{4}{|c|}{$F$ test that all $u_{-} i=0$} \\
\hline OSS model & $\begin{array}{c}\mathrm{F}(9,323) \\
11.90\end{array}$ & $\begin{array}{c}\text { Prob. }>\text { F } \\
0.0000\end{array}$ & $\begin{array}{l}\text { Decision } \\
\text { Reject } \mathrm{H}_{0}\end{array}$ \\
\hline \multicolumn{4}{|c|}{ Breusch Pagan Lagrange Multiplier for Random Effects } \\
\hline OSS model & $\begin{array}{c}\text { Wald chi2(9) } \\
91.09\end{array}$ & $\begin{array}{c}\text { Prob. > chi2 } \\
0.0000\end{array}$ & $\begin{array}{l}\text { Decision } \\
\text { Reject } \mathrm{H}_{0}\end{array}$ \\
\hline \multicolumn{4}{|c|}{ Hausman Test } \\
\hline OSS model & $\begin{array}{c}\text { chi2 (9) } \\
23.65\end{array}$ & $\begin{array}{c}\text { (Prob. > chi2) } \\
0.0049\end{array}$ & $\begin{array}{l}\text { Decision } \\
\text { Reject } \mathrm{H}_{0}\end{array}$ \\
\hline \multicolumn{4}{|c|}{ Wooldridge Test for Autocorrelation in Panel Data } \\
\hline \multicolumn{4}{|c|}{ Ho: no first-order autocorrelation } \\
\hline OSS model & $\begin{array}{c}\mathrm{F}(1,165) \\
18.830\end{array}$ & $\begin{array}{c}\text { Prob. > F } \\
0.0000\end{array}$ & $\begin{array}{l}\text { Decision } \\
\text { Reject } \mathrm{H}_{0}\end{array}$ \\
\hline
\end{tabular}


Table A2. Cont.

\begin{tabular}{|c|c|c|}
\hline \multicolumn{3}{|c|}{ Multicollinearity Diagnostic Test } \\
\hline \multicolumn{3}{|c|}{ Values of variance inflation factors (VIF) } \\
\hline Variable & VIF & $1 / \mathrm{VIF}$ \\
\hline Deposits to total assets (DTTA) & 1.44 & 0.693975 \\
\hline Age of institution (AGEI) & 1.41 & 0.711492 \\
\hline Interest rate spread (IRS) & 1.35 & 0.741270 \\
\hline Deposits to loans (DTL) & 1.27 & 0.784547 \\
\hline Number of members (NAM) & 1.25 & 0.799491 \\
\hline Volume of deposits (VD) & 1.10 & 0.905490 \\
\hline Percentage of woman members (PWM) & 1.08 & 0.922247 \\
\hline Demand deposit ratio (DDR) & 1.05 & 0.954543 \\
\hline Inflation rate (INFL) & 1.02 & 0.983989 \\
\hline Mean VIF & 1.22 & \\
\hline \multicolumn{3}{|c|}{ Harris -Tzavalis Unit-root Test for OSS } \\
\hline \multicolumn{3}{|c|}{ Ho: Panels contain unit roots } \\
\hline Statistic & $p$-value & Decision \\
\hline-3.2260 & 0.0006 & Reject Ho \\
\hline \multicolumn{3}{|c|}{ Modified Wald test for group-wise Heteroskedasticity in fixed effect regression model } \\
\hline \multicolumn{3}{|c|}{$\mathrm{H}_{\mathrm{o}}$ : Constant Variance } \\
\hline chi2 (166) & Prob. > chi2 & Decision \\
\hline OSS model & 0.0000 & Reject $\mathrm{H}_{0}$ \\
\hline
\end{tabular}

\section{References}

1. Alshehhi, A.; Nobanee, H.; Khare, N. The impact of sustainability practices on corporate financial performance: Literature trends and future research potential. Sustainability 2018, 10, 494. [CrossRef]

2. Caserta, M.; Monteleone, S.; Reito, F. The trade-off between profitability and outreach in microfinance. Econ. Model. 2018, 72, 31-41. [CrossRef]

3. Birchall, J. Resilience in a Downturn: The Power of Financial Cooperatives; ILO: Geneva, Switzerland, 2013.

4. Christen, R.P.; Lyman, T.R.; Rosenberg, R. Microfinance Consensus Guidelines: Guiding Principles on Regulation and Supervision of Microfinance; World Bank Publications: Washington, DC, USA, 2003.

5. Ledgerwood, J. Microfinance Handbook: An Institutional and Financial Perspective; World Bank Publications: Washington, DC, USA, 1998.

6. Ledgerwood, J.; Earne, J.; Nelson, C. The New Microfinance Handbook: A Financial Market System Perspective; World Bank Publications: Washington, DC, USA, 2013.

7. Branch, B.; Klaehn, J. Striking the Balance in Microfinance: A Practical Guide to Mobilizing Savings; Pact Publications: Birmingham, UK, 2002.

8. Marwa, N.; Aziakpono, M. Financial sustainability of tanzanian saving and credit cooperatives. Int. J. Soc. Econ. 2015, 42, 870-887. [CrossRef]

9. Sousa-Shields, M.D.; Frankiewicz, C. Financing Microfinance Institutions: The Context for Transitions to Private Capital Accelerated Microenterprise Advancement Project; United States Agency for International Development: Washington, DC, USA, 2004.

10. Brau, J.C.; Woller, G.M. Microfinance: A comprehensive review of the existing literature. J. Entrepreneurial Finance 2004, 9, 1.

11. Bos, J.W.B.; Millone, M. Practice what you preach: Microfinance business models and operational efficiency. World Dev. 2015, 70, 28-42. [CrossRef]

12. Railienè, G.; Sinevičienè, L. Performance valuation of credit unions having social and self-sustaining aim. Procedia Soc. Behav. Sci. 2015, 213, 423-429. [CrossRef]

13. Islam, M.S. Programmed Initiative, Reaching the Extreme Poor and MFI Sustainability: Mission Drift or Diseconomy? Institute of Microfinance (InM): Dhaka, Bangladesh, 2014. 
14. Bayai, I.; Ikhide, S. Financing and Financial Sustainability of Microfinance Institutions (MFIs): A Conceptual View; 2016.

15. Meyer, R.L. Track Record of Financial Institutions in Assisting the Poor in Asia; Asian Development Bank Institute: Tokyo, Japan, 2002.

16. Helms, B. Access for All: Building Inclusive Financial Systems; The World Bank: Washington, DC, USA, 2006.

17. Morduch, J.; Cull, R. Microfinance and economic development. In Handbook of Finance and Development; Edward Elgar Publishing: Cheltenham, UK, 2017.

18. Ayayi, A.G.; Sene, M. What drives microfinance institution's financial sustainability. J. Dev. Areas 2010, 44, 303-324. [CrossRef]

19. Rhyne, E. The yin and yang of microfinance: Reaching the poor and sustainability. MicroBanking Bull. 1998, 2, 6-8.

20. Bhanot, D.; Bapat, V. Sustainability index of micro finance institutions (MFIs) and contributory factors. Int. J. Soc. Econ. 2015, 42, 387-403. [CrossRef]

21. Hermes, N.; Lensink, R. Microfinance: Its impact, outreach, and sustainability. World Dev. 2011, 39, 875-881. [CrossRef]

22. Hermes, N.; Lensink, R.; Meesters, A. Outreach and efficiency of microfinance institutions. World Dev. 2011, 39, 938-948. [CrossRef]

23. Piot-Lepetit, I.; Nzongang, J. Financial sustainability and poverty outreach within a network of village banks in cameroon: A multi-DEA approach. Eur. J. Oper. Res. 2014, 234, 319-330. [CrossRef]

24. Guérin, I.; Labie, M.; Morvant-Roux, S. Inadequate growth, over-indebtedness, and crises in microcredit: What have we learned? Enterp. Dev. Microfinance 2018, 29, 118-132. [CrossRef]

25. Commission, N.P. The Second Growth and Transformation Plan (GTP II)(2015/16-2019/20)(Draft); The Federal Democratic Republic of Ethiopia: Addis Ababa, Ethiopia, 2015.

26. Tsiang, S.-C. Keynes's "finance" demand for liquidity, robertson's loanable funds theory, and friedman's monetarism. Q. J. Econ. 1980, 94, 467-491. [CrossRef]

27. Robertson, D.H. Industrial fluctuation and the natural rate of interest. Econ. J. 1934, 44, 650-656. [CrossRef]

28. Ohlin, B. Some notes on the stockholm theory of savings and investment I. Econ. J. 1937, 47, 53-69. [CrossRef]

29. Ohlin, B. Some notes on the stockholm theory of savings and investments II. Econ. J. 1937, 47, 221-240. [CrossRef]

30. Kohn, M. A loanable funds theory of unemployment and monetary disequilibrium. Am. Econ. Rev. 1981, $71,859-879$.

31. Leijonhufvud, A. Information and Coordination: Essays in Macroeconomic Theory; Oxford Univ Press: Oxford, UK, 1981.

32. Giancarlo, B. Some Observations about the Loanable Funds Theory; Department of Economics, University of Insubria: Varese, Italy, 2007.

33. Bogan, V.L. Capital structure and sustainability: An empirical study of microfinance institutions. Rev. Econ. Stat. 2012, 94, 1045-1058. [CrossRef]

34. Mahinda, W.; Jacob, Y.; Michele, M. Assessing the financial and outreach efficiency of microfinance institutions: Do age and size matter? J. Multinatl. Financ. Manag. 2017, 40, 63-76.

35. Morduch, J. The microfinance schism. World Dev. 2000, 28, 617-629. [CrossRef]

36. Woller, G.M.; Dunford, C.; Woodworth, W. Where to microfinance. Int. J. Econ. Dev. 1999, 1, $29-64$.

37. CGAP. CGAP-Consensus-Guidelines-Developing-Deposit-Services-for-the-Poor; The World Bank Group: Washington, DC, USA, 2005.

38. Elser, L.; Hannig, A.; Wisniwski, S. Comparative Analysis of Savings Mobilization Strategies; Working Group on Savings Mobilization, CGAP: Eschborn, Germany, 1999.

39. Fiebig, M.; Hannig, A.; Wisniwski, S. Savings in the Context of Microfinance-State of Knowledge; Working Group on Savings Mobilization, GTZ y CGAP: Eschborn, Germany, 1999.

40. Mukherjee, J.; Wisniwski, S. Savings Mobilization Strategies: Lessons from Four Experiences; CGAP: Eschborn, German, 1998.

41. Hartarska, V.; Parmeter, C.F.; Nadolnyak, D. Economies of scope of lending and mobilizing deposits in microfinance institutions: A semiparametric analysis. Am. J. Agric. Econ. 2011, 93, 389-398. [CrossRef]

42. Smith, D.J.; Cargill, T.F.; Meyer, R.A. Credit union. J. Finance 1981, 36, 519-528. 
43. Mwizarubi, M.; Singh, H.; Mnzava, B.; Prusty, S. Emerging paradigms of financing tanzanian microfinance institutions and their impact on financial sustainability-Part I. World J. Soc. Sci. 2016, 6, 32-44.

44. Kinde, B.A. Financial sustainability of microfinance institutions (MFIs) in Ethiopia. Eur. J. Bus. Manag. 2012, 4, 1-10.

45. Microfinance Profitability: Does Financing Choice Matter? Available online: https://www.rug.nl/research/ globalisation-studies-groningen/research/conferencesandseminars/conferences / eumicrofinconf2011/ papers/1new.3c.muriu.pdf (accessed on 30 May 2011).

46. Tehulu, T.A. Determinants of financial sustainability of microfinance institutions in East Africa. Eur. J. Bus. Manag. 2013, 5, 152-158.

47. Microfinance Institutions: Does Capital Structure Matter? Available online: https://poseidon01.ssrn. com/delivery.php?ID=0310910040860660200980930650961020180210400010440490261091051120951100270 31123122110101005043014122099042090127000108078090085052020066046041115090102119125119091065060 $08602812109106506707900108706812708108400609708010809408102 \quad 2025070126005125005101 \& E X T=p d f$ (accessed on 16 May 2008).

48. Yaron, J. What makes rural finance institutions successful? World Bank Res. Obs. 1994, 9, 49-70.

49. Agapova, A.; McNulty, J.E. Interest rate spreads and banking system efficiency: General considerations with an application to the transition economies of central and eastern europe. Int. Rev. Financ. Anal. 2016, 47, 154-165. [CrossRef]

50. Esho, N. The determinants of cost efficiency in cooperative financial institutions: Australian evidence. J. Bank. Finance 2001, 25, 941-964. [CrossRef]

51. Rubin, G.M.; Overstreet, G.A.; Beling, P.; Rajaratnam, K. A dynamic theory of the credit union. Ann. Oper. Res. 2013, 205, 29-53. [CrossRef]

52. Tesfamariam, S.K. Saving behaviour and determinants of saving mobilization by rural financial co-operators in Tigrai Region, Ethiopia. J. Agribus. Rural. Dev. 2012, 4, 129-146.

53. Financial Sustainability and Outreach of Microfinance Institutions in Ethiopia: Does Organizational Form Matter? Available online: https://papers.ssrn.com/sol3/papers.cfm?abstract_id=2288627 (accessed on 13 June 2018).

54. Abay, A.K.; Koru, B.; Abate, G.T.; Berhane, G. How should rural financial cooperatives be best organized? Evidence from Ethiopia. Ann. Public Coop. Econ. 2017. [CrossRef]

55. Tirfe, A. Financial performance of rural saving and credit cooperatives in tigray, Ethiopia. Res. J. Finance Account. 2014, 5, 63-74.

56. Tesfamariam, K. Savings and credit cooperatives in Ethiopia: Development and challenges. J. Econ. Sustain. Dev. 2014, 6.

57. Emana, B. Cooperatives: A Path to Economic and Social Empowerment in Ethiopia; ILO: Geneva, Switzerland, 2009.

58. Brain, B.; Klaehn, J. Striking the Balance in Microfinance: A Practical Guide to Savings Mobilization, Lessons from Credit Unions in Latin America; Pact Publications for World Council of Credit Unions, Inc.: Washington, DC, USA, 2002.

59. Getachew, M. Sustainable SACCO Development: Training Material. Chemonics International Inc. 2016. Available online: http:/ / www.usaid.gov/pdf_docs/PNADK962.pdf (accessed on 18 September 2017).

60. Mwangi, M.; Muturi, W.; Ombuki, C. The effect of deposit to asset ratio on the financial sustainability of deposit-taking microfinance institutions in Kenya. Int. J. Econ. Commer. Manag. 2015, 3, 504-511.

61. Marakkath, N. Sustainability of Indian Microfinance Institutions: A Mixed Methods Approach; Springer: New York, NY, USA, 2013.

62. Abdulai, A.; Tewari, D.D. Trade-off between outreach and sustainability of microfinance institutions: Evidence from sub-Saharan Africa. Enterp. Dev. Microfinance 2017, 28, 162-181. [CrossRef]

63. Lensink, R.; Mersland, R.; Vu, N.T.H.; Zamore, S. Do microfinance institutions benefit from integrating financial and nonfinancial services? Econ. 2017, 50, 2386-2401.

64. Quayes, S. Outreach and performance of microfinance institutions: A panel analysis. Appl. Econ. 2015, 47, 1909-1925. [CrossRef]

65. Rosenberg, R. Measuring Results of Microfinance Institutions: Minimum Indicators That Donors and Investors Should Track—A Technical Guide; World Bank Publications: Washington, DC, USA, 2009. 
66. Imai, K.S.; Gaiha, R.; Thapa, G.; Annim, S.K.; Gupta, A. Financial Performance of Microfinance Institutions - A Macroeconomic and Institutional Perspective; Discussion Paper Series: DP2012-04; Research Institute for Economics \& Business Administration, Kobe University: Kobe, Japan, 2012.

67. Zhang, K.Q.; Chen, H.H. Environmental performance and financing decisions impact on sustainable financial development of chinese environmental protection enterprises. Sustainability 2017, 9, 2260. [CrossRef]

68. Zhou, H.; Yang, Y.; Chen, Y.; Zhu, J. Data envelopment analysis application in sustainability: The origins, development and future directions. Eur. J. Oper. Res. 2018, 264, 1-16. [CrossRef]

69. Wooldridge, J.M. Introductory Econometrics: A Modern Approach; Nelson Education: Scarborough, ON, Canada, 2015.

70. Lomax, R.G.; Schumacker, R.E. A Beginner's Guide to Structural Equation Modeling; Routledge Academic: New York, NY, USA, 2012.

71. Lotto, J. The empirical analysis of the impact of bank capital regulations on operating efficiency. Int. J. Financ. Stud. 2018, 6, 34. [CrossRef]

72. Harris, R.D.; Tzavalis, E. Inference for unit roots in dynamic panels where the time dimension is fixed. J. Econom. 1999, 91, 201-226. [CrossRef]

73. Nachane, D.M. Econometrics: Theoretical Foundations and Empirical Perspectives; OUP Catalogue; Oxford University Press: Oxford, UK, 2006.

74. Damodar, N. Basic Econometrics; The Mc-Graw Hill: New York, NY, USA, 2004.

75. Le Polain, M.; Sterck, O.; Nyssens, M. Interest rates in savings groups: Thrift or threat? World Dev. 2018, 101, 162-172. [CrossRef]

76. Cozarenco, A.; Hudon, M.; Szafarz, A. What type of microfinance institutions supply savings products? Econ. Lett. 2016, 140, 57-59.

77. Boehe, D.M.; Barin Cruz, L. Gender and microfinance performance: Why does the institutional context matter? World Dev. 2013, 47, 121-135. [CrossRef]

78. Abdullah, S.; Quayes, S. Do women borrowers augment financial performance of mfis? Appl. Econ. 2016, $48,5593-5604$.

79. Gutierrez-Goiria, J.; San-Jose, L.; Retolaza, J.L. Social efficiency in microfinance institutions: Identifying how to improve it. J. Int. Dev. 2017, 29, 259-280. [CrossRef]

(C) 2018 by the authors. Licensee MDPI, Basel, Switzerland. This article is an open access article distributed under the terms and conditions of the Creative Commons Attribution (CC BY) license (http:/ / creativecommons.org/licenses/by/4.0/). 